\title{
A RÓMAI BÉLYEGES TÉGLÁK ÉS KERÁMIA ÉPÍTŐANYAGOK (CBM) FELDOLGOZÁSÁRA KIALAKIITOTT CLIR ADATBÁZIS MODUL BEMUTATÁSA ${ }^{1}$
}

\section{FARKAS István Gergö ${ }^{2}$}

Magyar Régészet 10. évf. (2021), 4. szám, pp. 18-26. https://doi.org/10.36245/mr.2021.4.2

A római határvédelmi kutatások egyik régi témája a tárgya jelen tanulmánynak. A téglabélyegek elemzése, ami az utóbbi évtizedekben kiegészült a sokkal általánosabb kerámia építöanyagok (CBM) vizsgálatával, számos eredményt hozott a limes kutatásában. Kezdve olyan hagyományosnak számító kutatási kérdésektöl, mint a segédcsapatok állomástörténete (dislocatio) és az épített emlékek kronológiája, egészen az újabb megközelítésü elemzésekig, mint a tájrégészet vagy a spolia-emlékek vizsgálata, a római kerámia épitöanyagok számos tudományos kérdésre adnak választ. A CBM leletek rendkivül sokrétü tárgycsoportot alkotnak, egyaránt szolgáltatnak adatot természettudományos és epigráfiai/ikonográfiai vizsgálatokhoz. A római CBM leletek puszta mennyisége megkerülhetetlenné teszi a feldolgozásuk során az adatbázisok alkalmazását. Jelen cikk az új fejlesztésü CLIR adatbázissal egy kipróbált, széleskörüen használható megoldást kinál ennek a gazdag leletcsoportnak a feldolgozására és tudományos értékelésére.

Kulcsszavak: kerámia építőanyagok (CBM), latin epigráfia, többirányú megvilágításos képalkotás (H-RTI), régészeti adatbázis

\section{BEVEZETÉS}

Római téglákat, különösen a bélyeggel vagy karcolt feliratokkal, díszekkel ellátott ép példányokat a régiségbúvárok a reneszánsz óta gyüjtik, ahogy ezt korabeli források is tanúsítják. A legtöbb újkori epigráfiai gyüjteményből nem hiányoztak a jelölt téglák (sem más instrumenta inscripta, ToRMA 1883), ugyanakkor e forrásanyag többségét adó jelöletlen kerámia építőanyagok (CBM) érthető okból csak elvétve kerültek régiségtárakba. ${ }^{3}$ Magyarországon a jelölt téglák kutatása tekintélyes múlttal bír, a 19. század óta folyamatosan jelennek meg mind átfogó feldolgozások (PósTA 1897; WosinsKy 1896), mind helyi vonatkozású közlemények (Grosschmied 1836; Rómer 1886).

A CBM vizsgálata mint nyersanyag, építészeti alapanyag és ipari termék, nem újkeletü. Nagy menynyiségü téglaanyag tudományos igényü feldolgozásának módszertanának alapjait már az 1970-es években lefektették Angliában, azóta a módszereket fokozatosan tökéletesítették (McWHIRR 1978). Véletlenszerü mintavétellel kiválasztott darabokon végzett anyagvizsgálatokból levont következtetések a téglák, csapatok és bélyegzők szállításának számos kérdését megválaszolták, emellett elkülöníthetővé tették a különböző mühelyekben készített téglákat és feltérképezhetővé tettek számos szállítási útvonalat. Hasonló kutatásokra Magyarországon a 2000-es évek elején került sor, Kovács Lóránd Olivér (KovÁcs 2003; 2005) és Havas Zoltán (HAVAS 2005; 2019) doktori disszertációi fontos mérföldköveket jelentenek a pannoniai CBM kutatásában. Munkájuk során a szerzők a CBM kutatás nemzetközileg kialakított kereteit vették alapul és megalkották a kapcsolódó magyar nevezéktant, irányt mutatva a hazai leletanyag jövőbeli feldolgozásához. Napjainkig mindössze néhány lelőhely és építmény CBM anyagának teljeskörü feldolgozása valósult

\footnotetext{
Az előadás az Európai Régészszövetség 26. Virtuális Éves Konferenciáján hangzott el 2020. augusztus 29-én „Building Empires - New Research on CBM and Stamped Tiles on Roman Frontiers - Introducing the CLIR Research Center and Limes Database" címmel.

2 Völgységi Múzeum. E-mail: farkas.istvan.gergo@gmail.com

3 A pannoniai téglák vonatkozásában a legfontosabb epigráfiai gyüjtemények a Corpus Inscriptionum Latinarum (CIL) és a Römische Inschriften Ungarns (RIU) sorozatai, emellett téglafeliratokat számos regionális és tematikus tudományos mü közölt. Pannoniai vonatkozású online epigráfiai adatbázisok, mint a Heidelbergi Epigráfiai Adatbázis (EDH: https://edh-www. adw.uni-heidelberg.de/home), az Ubi Erat Lupa (http://lupa.at/), valamint számos más digitális epigráfiai és ikonográfiai gyüjtemény is folyamatosan bővül római téglafeliratokkal és jelölésekkel.
} 
Farkas István Gergö • A római bélyeges téglák és kerámia épitöanyagok (CBM) feldolgozására kialakitott CLIR adatbázis

meg, köztük Szőny-Vásártér (BorHY \& SzÁMADÓ 1999; összefoglaló BorHy 2014), valamint Tác-Gorsium/ Herculia (KovÁcs 2005) egyes épületei, illetve a Hajógyári-szigeten feltárt helytartói palota (HaVAs 2019). Ugyanakkor a CBM leletek részletes adatrögzítése egyre elfogadottabb és a rendelkezésre álló leletanyag minden évben jelentős mértékben nő, hála annak, hogy az utóbbi évtizedekben a kutatás fel- és elismerte a CBM leletekben rejlő információ tudományos értékét. Pannonia viszonylatában jelenleg a BTM Aquincumi Múzeuma rendelkezik a legjelentősebb gyűjteménnyel, mintegy tízezer téglával (Havas 2019, 72, 131. 1j.), ezt követi a bécsi Stadtmuseum, a Vindobonából származó mintegy négyezer téglával (tegula. org). ${ }^{4}$ További megyei és városi múzeumok (pl. Komárom, Székesfehérvár, Dunaújváros) a limes mentén és a hátországban néhány száz téglát tartanak nyilvántartásban.

\section{AZ ADATGYÜJTÉS MÓDSZERTANA}

Nagy mennyiségü CBM és nyersagyaglelet hatékony és részletgazdag dokumentációjának módjait már a hetvenes években megalkották, a kipróbált módszertan mögött gazdag szakirodalom áll (McWHIRR 1979; 309-401; McComish s. a.; Desbat 1981, 55-81; Ferdière 2012). Kezdve a kiterjedt terepi adatgyüjtés módszertanától (McСомISH 2015), a mintavételezésen (McСомISH 2015) és funkció szerinti osztályozáson át (HAVAs 2019, 74) a különböző mühelyek elkülönítéséig (Havas, 2019, 75), valamint a rajzolatok és jelölések osztályozásáig (WARRY 2006, 91; BRODRIBB 1989, 102) és a téglagyártás és az építkezések adminisztratív vonatkozásaiig (AUBERT 2005, 53-59). A korábbi kutatások során számos olyan kérdés merült fel, amire a CBM feldolgozása adott választ. Ennek eredményeképpen a téglák alapanyagának bányászata (CLEMENT 2016, 146-148), gyártásának folyamata (megformálás, égetés, felületkezelés) és az ennek során használt eszközök tekintetében, valamint a téglák tipológiája és a rajtuk használt jelölések döntő többségének a tekintetében szakmai konszenzus alakult ki. A nevezéktan fordításai az érintett nyelvterületeken elkészültek, a német terminológiát Wolfgang Czysz (CzYsz 2001, 146-151), a magyar nevezéktant Kovács Loránd Olivér (KovÁcs 2005) és Havas Zoltán (Havas 2019) állították össze.

1. táblázat. A CLIR adatbázis lelet moduljában a CBM leletek vonatkozásában elsödlegesen rögzitett adatok. A csillaggal (*) jelölt adatok rögzítendök terepi feldolgozás során

\begin{tabular}{|c|c|c|}
\hline Nr. & Adattípus & Adattípus az adatbázisban \\
\hline 1 & $\begin{array}{l}\text { Azonosítás } \\
\text { Lelet azonosító*, Leltári szám, Gyarapodási napló szám, } \\
\text { más adatbázisok és gyüjtemények azonosítói }\end{array}$ & $\begin{array}{l}\text { Egyedi azonosítók sora, az online gyüjteményekhez linkek } \\
\text { (URL) }\end{array}$ \\
\hline 2 & $\begin{array}{l}\text { Lelöhely lokalizációja (a lehető legpontosabban, kezdve } \\
\text { modern közigazgatási helyszínektől egészen régészeti } \\
\text { jelenségek szintjéig)* }\end{array}$ & $\begin{array}{l}\text { Lelőhelyek, jelenségek és leletek elhelyezkedését és a köz- } \\
\text { tük fennállt kapcsolatot érzékeltető poligonok, vonalláncok } \\
\text { (polyline) és középponti koordináták }\end{array}$ \\
\hline 3 & Téglaforma (tipológiák nyomán) & $\begin{array}{l}\text { Többlépcsős taxonómiából (taxonomy term tree) töb- } \\
\text { bválasztós érték }\end{array}$ \\
\hline 4 & $\begin{array}{l}\text { Méretadatok (a formák változatossága miatt egy összetett } \\
\text { méretadatrendszer szükséges, } \sim 0.5 \mathrm{~cm} \text { és } 1^{\circ} \text { pontosság- } \\
\text { gal) }\end{array}$ & $\begin{array}{l}\text { Lelőhely / jelenség / lelet alapján különböző méretadatok } \\
\text { sora }\end{array}$ \\
\hline 5 & $\begin{array}{l}\text { Jelölések (számolási jegyek, díszítések, rajzok, tágabban } \\
\text { minden, ujjal vagy szerszámmal tett jelölések) }\end{array}$ & $\begin{array}{l}\text { Többlépcsős taxonómiából (taxonomy term tree) töb- } \\
\text { bválasztós érték }\end{array}$ \\
\hline 6 & Feliratok (vésett, festett, bélyegzett, karcolt feliratok) & $\begin{array}{l}\text { Szövegként rögzített átirat és feloldás (Leideni kulcs } \\
\text { szerint); attribútumok (lelet funkciója, vésés módja, } \\
\text { díszítőelemek stb.) rögzítése többlépcsős taxonómiából } \\
\text { (taxonomy term tree) többválasztós értékként; méretadatok } \\
\text { rögzítése önálló adatsorokként }\end{array}$ \\
\hline
\end{tabular}

4 https://www.interactive-art.at/crazy-eye/WebGIS/Gestempelte-Ziegel-aus-Vindobona/\#15/48.2022/16.3731 
Farkas István Gergö • A római bélyeges téglák és kerámia épitöanyagok (CBM) feldolgozására kialakitott CLIR adatbázis

\begin{tabular}{|c|c|c|}
\hline Nr. & Adattípus & Adattípus az adatbázisban \\
\hline 7 & $\begin{array}{l}\text { Bélyegek (téglabélyegek minden adata, pl. méretek, } \\
\text { szöveg, típus) }\end{array}$ & $\begin{array}{l}\text { Szövegként rögzített átirat és feloldás (Leideni kulcs } \\
\text { szerint); attribútumok (lelet funkciója, vésés módja, } \\
\text { díszítőelemek stb.) rögzítése többlépcsős taxonómiából } \\
\text { (taxonomy term tree) többválasztós értékként; méretadatok } \\
\text { rögzítése önálló adatsorokként }\end{array}$ \\
\hline 8 & $\begin{array}{l}\text { Állatnyomok (archeozoológiai vizsgálat nyomán } \\
\text { véglegesítendő) }\end{array}$ & Szöveges leírás \\
\hline 9 & Szín (Pantone vagy egyenértékü színskála nyomán) & Szöveges leírás, kalibrált színkódok \\
\hline 10 & $\begin{array}{l}\text { Pozíció (töredékes téglák esetén a töredék pozíciója a } \\
\text { tégla egészéhez viszonyítva) }\end{array}$ & Szöveges leírás \\
\hline 11 & $\begin{array}{l}\text { Feldolgozás (bármilyen, gyártáshoz kapcsolódó technikai } \\
\text { részlet) }\end{array}$ & $\begin{array}{l}\text { Szöveges leírás és többlépcsős taxonómiából (taxonomy } \\
\text { term tree) többválasztós érték }\end{array}$ \\
\hline 12 & $\begin{array}{l}\text { Anyagszerkezet (alapanyag, kötőanyagok és } \\
\text { szennyezödések) }\end{array}$ & $\begin{array}{l}\text { Szöveges leírás és többlépcsős taxonómiából (taxonomy } \\
\text { term tree) többválasztós érték }\end{array}$ \\
\hline
\end{tabular}

2. táblázat. CBM leletek kapcsán rögzített másodlagos adatok

(terepen, illetve elsödleges feldolgozás során rögzitett adatok későbbi kiegészitése)

\begin{tabular}{|r|l|l|}
\hline Nr. & Adattípus & Adattípus az adatbázisban \\
\hline 1 & $\begin{array}{l}\text { Örzés körülményei (leletet kezelö intézmény és/vagy } \\
\text { gyüjtemény, nyilvántartásba vétel időpontja, revíziók, } \\
\text { gyarapodás módja és részletei, gyarapító neve stb.) }\end{array}$ & $\begin{array}{l}\text { Szöveges leírás és többlépcsős taxonómiából (taxonomy } \\
\text { term tree) többválasztós érték; valamint kiegészítő elemek- } \\
\text { ként (node) rögzített személyek, intézmények és kutatási } \\
\text { tevékenységek }\end{array}$ \\
\hline 2 & $\begin{array}{l}\text { Szakirodalom az egyes téglák vagy típusok } \\
\text { vonatkozásában }\end{array}$ & Zotero bejegyzések \\
\hline 3 & Gyártási technika & $\begin{array}{l}\text { Többlépcsős taxonómiából (taxonomy term tree) töb- } \\
\text { bválasztós érték }\end{array}$ \\
\hline 4 & $\begin{array}{l}\text { Lelet állapota } \\
\text { Többlépcsós taxonómiából (taxonomy term tree) töb- } \\
\text { bválasztós érték }\end{array}$ \\
\hline 5 & $\begin{array}{l}\text { Megjegyzés vagy kiegészítés (jelen állapot, tárolási } \\
\text { körülmények, megjegyzések) }\end{array}$ & $\begin{array}{l}\text { Szöveges leírás és többlépcsős taxonómiából (taxonomy } \\
\text { term tree) többválasztós érték }\end{array}$ \\
\hline
\end{tabular}

A CBM kutatás kiindulópontját a fenti adatok jelentik, ezeket szükséges regionális, elsősorban antik vonatkozású sajátosságokkal kiegészíteni, mint a római mértékegységekben megfigyelhető területi eltérések, különböző környezeti viszonyok és tájegységenként változó építészeti módszerek és megoldások. Bizonyos regionális jellemzők korunkbeli tényezőkre vezethetők vissza, így az ásatás körülményeire és alkalmazott módszerekre, a dokumentációs gyakorlatra és a tárolás feltételeire. Különösen Kelet- és DélEurópában világháborúk pusztításait a megszállás évtizedei is súlyosbították, mivel számos régészeti tárgy és a hozzájuk kapcsolódó nyilvántartás megsemmisült, ez a veszteség napjainkban is nehezíti a leletanyag feldolgozását és kiértékelését végzők munkáját.

\section{A DIGITÁLIS DOKUMENTÁCIÓ MÓDSZERTANA}

A múlt században a jelölt téglák felszínének rögzítésére leggyakrabban egyszerű rajzolatot, régebben főleg átsatírozást, ritkábban pacskolatot alkalmazott a kutatás. Újabban a színhelyes, illetve súrlófényes fotódokumentáció az általánosan alkalmazott dokumentációs eljárás, mindkettő gyors, megbízható és tárhelybarát megoldás. A téglák és CBM leletek felületén található jelenségek, illetve a tárgyak teljes felszínének részletgazdag rögzítését fotogrammetriai, illetve lézerszkennelt 3D modellek teszik lehetővé, azonban mindkettő eszköz- és időigényes.

Egy hathatós digitális dokumentációs alternatívát jelent az ún. többirányú megvilágításos képalkotás (Highlight Reflectance Transformation Imaging - H-RTI, más néven Multi Light Imaging), ennek során 
Farkas István Gergö • A római bélyeges téglák és kerámia épitöanyagok (CBM) feldolgozására kialakitott CLIR adatbázis

egy elsötétített térben a dokumentálandó felületre merőlegesen rögzített fényképezőgéppel fotósorozatot készítünk a dokumentálandó tárgy felületéröl változó irányú, de egységes intenzitású (a felülettől azonos távolságra elhelyezett) pontszerü fényforrással való megvilágítás mellett. A H-RTI eljárás egy 2,5 dimenziós modellt eredményez, amin a tetszőleges irányú megvilágítás szimulálható, valamint a felületből kiemelkedő vagy abba bemélyedő jelenségek algoritmussal kihangsúlyozhatók. Ebből adódóan a módszer erőssége lapos tárgyak és kopott felületek dokumentálásában és értelmezésének elösegítésében rejlik (1. kép).

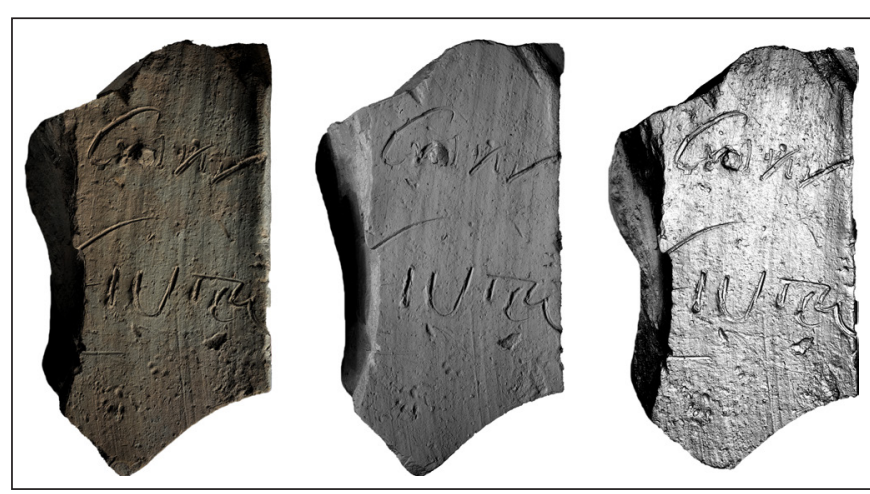

1. kép. Karcolt feliratos római tégla H-RTI módszerrel készitett 2,5 dimenziós modelljéröl készitett fotók többféle megvilágításból (Készitette: Farkas István Gergö)

A H-RTI modell készítésének eszközigénye megegyezik a tárgyfotózáséval, a legtöbb DSLR/MILC váz és alapobjektív alkalmas jó minőségü fotók készítésére. A H-RTI modellhez használt szoftver nyílt forráskódú, ${ }^{5}$ szabadon alkalmazható, alacsony hardverigényü (a napjainkban használt többmagos processzorokkal zökkenőmentes munka végezhető). A tárgyak fotózása (ideális részletességű modell 40-50 fényképből készíthetö) 1-2, a modellek generálása 5-10 percet igényel.

A H-RTI módszertanát Tom Malzbender dolgozta ki munkatársaival 2001-ben (MalzBender, GelB \& Wolters 2001), az elmúlt két évtizedben a módszer a nemzetközi kutatásban is teret hódított. Részben a technikai fejlődés nyomán, részben a feldolgozott leletanyag nagy mennyisége és sokszínüsége eredményeképpen a módszert pontosították és napjainkban számos szakcikk és technikai dokumentáció érhető el, amivel a módszer adott leletanyagra testre szabható. ${ }^{6}$

\section{A CLIR ADATBÁZIS CBM MODULJA}

A CBM kutatás nem függetleníthető leletanyag adottságaitól: a feldolgozandó anyag puszta mennyisége lenyügöző, a Yorkból gyüjtött római téglák mennyisége meghaladja a 8,11 tonnát (McCoMisH s. a., 1, 66), ugyanakkor ez a hihetetlen mennyiségű anyag viszonylag jól leírható egy letisztult tipológiával, mindemellett az egyes CBM leletek elökerülési körülményei tekintetében rendkívül nagy a szórás, teljesen dokumentált ásatásról napvilágra került darabok mellett számos lelet lelöhelye kérdéses vagy visszakövethetetlen. Ezek miatt a sajátosságok miatt kézenfekvő, hogy az anyag feldolgozása és vizsgálata egy online régészeti adatbázisra épüljön. Az adatbázis online mivolta a nemzetközi együttmüködés kulcsa, aminek hiányában az anyag feldolgozása elaprózódik sok, egymással csak nagyrészt megfeleltethető lokális adattárban.

A nemzetközi együttmüködés volt az a cél, amiért a Római Birodalom határainak régészeti helyszíneit és jelenségeit magába foglaló Corpus Limitum Imperii Romani (CLIR) adatbázis létrejött, egy mintegy öt évtizedre visszatekintő kutatási program kiteljesítéseként (VISY 2015, 929-929; FARKAS 2019, 159-165).

Más hasonló rendszerekhez képest a CLIR adatbázis fó újítása az a kimondott célkitüzés, hogy a régészeti lelöhelyeket és jelenségeiket a maguk teljes összetettségében dokumentálja, ugyanakkor áttekinthető és kezelhető formában tegye elérhetővé. Az adatbázis szerkezetének kialakítása során három fő buktatót kellett elkerülni, ezek közül az első a túlegyszerüsítés volt: ha egy adatbázis nem képes tükrözi a lokalizáció elkerülhetetlen pontatlanságait, az összefüggések különböző értelmezéséből fakadó különbségeket, akkor tudományos elemzés céljára alkalmatlan és legjobb esetben jövőbeli kutatások alapjául szolgáló adattárként működhet. Szintén zsákutcába vezet a régészeti jelenségeknek egy adott tudományos álláspont szerint helytálló, de a későbbiekben megváltoztathatatlan, rugalmatlan adatsorokként való rögzítése, ami idővel ellehetetleníti új eredmények és adatok átvételét és hosszútávon fenntarthatatlanná teszi a gyüjteményt. A

http://culturalheritageimaging.org/

6 A vonatkozó szakirodalom akár csak vázlatos ismertetése is meghaladja jelen cikk kereteit, ezért mindössze egy válogatást adok közre a kapcsolódó cikkekből és útmutatókból: https://www.loc.gov/preservation/digital/formats/fdd/fdd000486.shtml 
Farkas István Gergö• A római bélyeges téglák és kerámia épitöanyagok (CBM) feldolgozására kialakitott CLIR adatbázis

harmadik elkerülendő veszélyt az adatbázis megalapozatlan szakmaiságú fejlesztése jelentette - az adatbázis fejlesztés egy teljes értékű szakma a saját szabványaival és jó gyakorlataival, ugyanakkor számos olyan régészeti adatbázissal találkozhatunk, ami adatbázistervezés vagy integritásvizsgálat nélkül lett fejlesztve.

A https://clir.hu oldalon elérhető CLIR adatbázist a fenti szempontok figyelembevételével alakítottuk ki. Ennek az objektumorientált adatbázisnak a szerkezete és müködése külön tanulmány tárgya (FARKAS 2021, 23-34). Röviden összefoglalva, ez egy különbözö, egymással korlátlanul összekapcsolható elemekböl (node) álló adatbázis, amiben az egyes elemeket különböző hierarchikus rendben rögzített tulajdonságokkal jellemezhetünk (taxonomy term tree). Az adatbázis négy fö elemtípusra épül, ezek a Lelöhelyek (Sites), Lelöhely részek (Site components), Alkotóelemek (Component parts) és Leletek (Finds). Ezekkel leírható egy teljes régészeti lelőhely, kezdve a legfelső Lelőhely szinttől, ami felbontható különálló egységekre (pl. egyes épületekre, szerkezeti elemekre stb.), amik tovább bonthatók önálló régészeti jelenségekre (pl. göd-

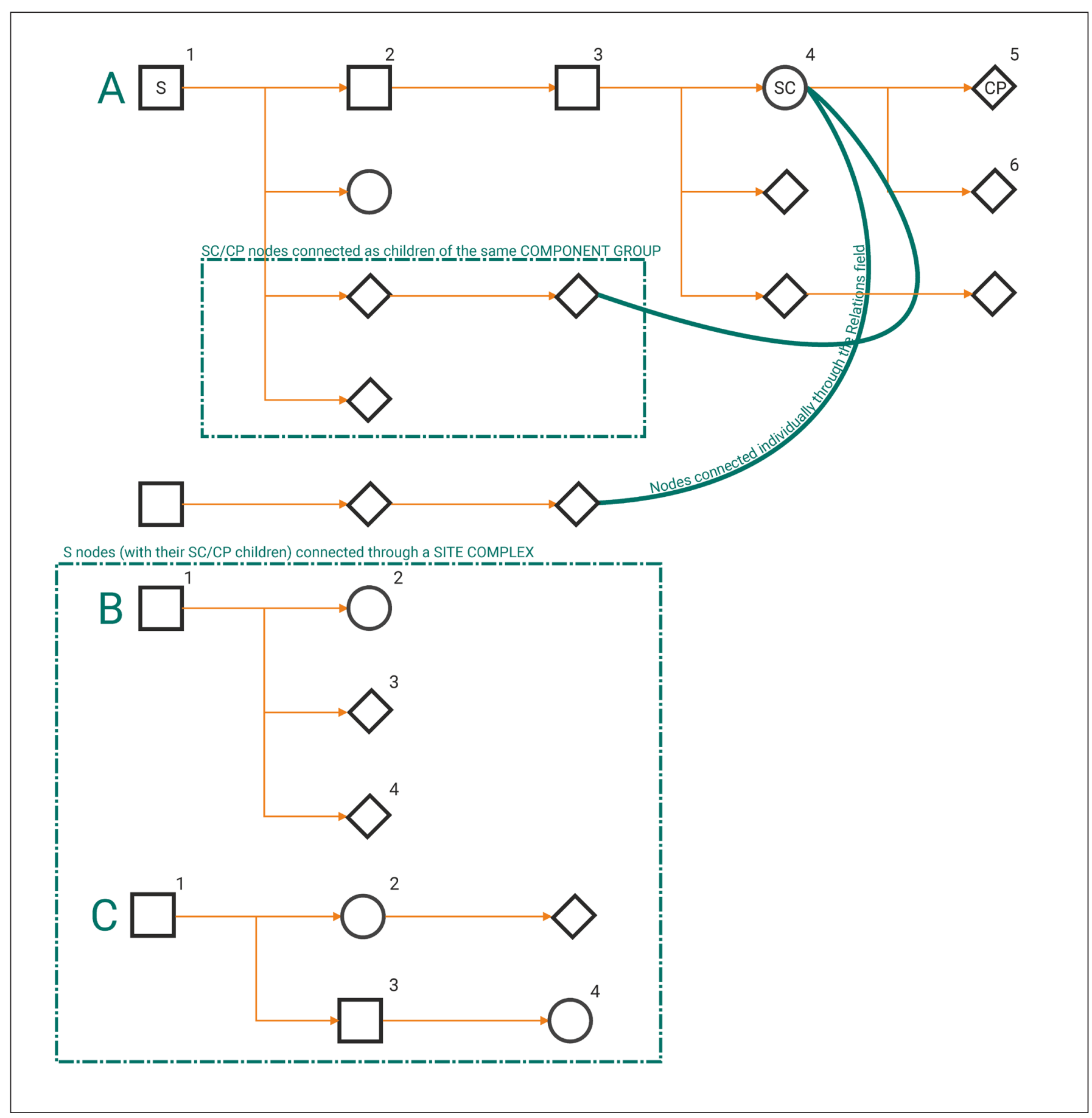


Farkas István Gergö • A római bélyeges téglák és kerámia épitöanyagok (CBM) feldolgozására kialakitott CLIR adatbázis

rök, betöltések, rétegek stb.). A kapcsolat ezek között az elemtípusok között egyirányú, ami azt jelenti, hogy egy Lelöhely kizárólag egy másik Lelöhely gyermeke (adatbázisban alárendelt része) lehet, más elemtípusé nem, ugyanakkor több Lelöhely között a szülö-gyermek kapcsolatok láncolata korlátlan (2. kép).

Különböző Lelöhelyek eltérő számú elemböl állhatnak (különböző számú gyermekük lehet), szülö-gyermek kapcsolatok eltérő láncolatában. Az ábrán példaként említett „A” Lelőhely tizenkét elemből és öt szintből áll, „B” Lelőhely három elemből és két szintből, „C” Lelőhely pedig négy elemből és három szintből. Az adatbázisban a szülő-gyermek kapcsolatok száma és a gyermekek száma egyaránt korlátlan. Az egyes elemek többféleképpen kapcsolhatók össze. Egy szülö gyermekei közül ki lehet választani tetszölegeset egy Részcsoportba (Component group), pl. egy római segédtábor falszakaszai, valamint kapu-, sarok- és közbülső tornyai alkothatnak egy „védművek” névre keresztelt Részcsoportot. Több Lelöhely különböző elemei összekapcsolhatók lelöhelyeken átívelö Lelőhely komplexumokba (Site complexes), pl. a Saxon partvidék erődítményei alkothatnak egy komplexumot, ugyanígy több tetszőleges limes-szakasz is leképezhető az adatbázisban.

Ez a rendszer kellően rugalmas ahhoz, hogy eltérő összetettségủ régészeti lelőhelyeket egyaránt kezeljen. Példának okáért egy római őrtorony egy meglehetősen egyszerü építmény (ld. „B1” elemet az 2. képen), ami áll egy toronyépületböl („B2”), amit egy sánc („B3”) és egy árok („B4”) övez. Ezzel szemben az ókori Pompeii városa („A1”) egy meglehetősen összetett lelöhely, azonban mérete ellenére lehetséges felbontani kerületek („A2”), háztömbök („A3”), épületek („A4”), szobák („A5”) és falak („A6”) komplex rendszerére.

Egyedi megoldások, mint egy táborhoz épített bővítmény Lelőhelyként (fort annex, „C3”) hozzárendelhetők az adatbázisban ahhoz a szintén Lelőhelyként rögzített táborhoz („C2”, amihez hozzáépítették öket. A bővítmény egy épülete („C4”) ily módon kapcsolódik az eredeti táborhoz. Ezeknek a kapcsolatoknak a természetét az adatbázis hierarchiája tükrözi, a kapcsolat pontos mibenléte és részletei a szöveges leírásokban pontosíthatók.

A CLIR adatbázisban történő tartalomrögzítés esetében a kulcsszó az, hogy lehetséges. Bár az adatbázisban lehetőség nyílik elképesztő részletességgel rögzíteni lelöhelyeket, a rendszer nem kötelezi a feltöltőket, hogy minden lehetséges adatot feltöltsenek, így nem ró teljesíthetetlen és végtelenül időigényes feladatokat azokra, akiknek nem áll módjukban teljesíteni ezt. Létre lehet hozni egy lelőhely keretét és később, utólagosan, esetleg egy nyertes pályázat keretében, a szükséges kutatási célokkal párhuzamosan ki lehet egészíteni a keretet.

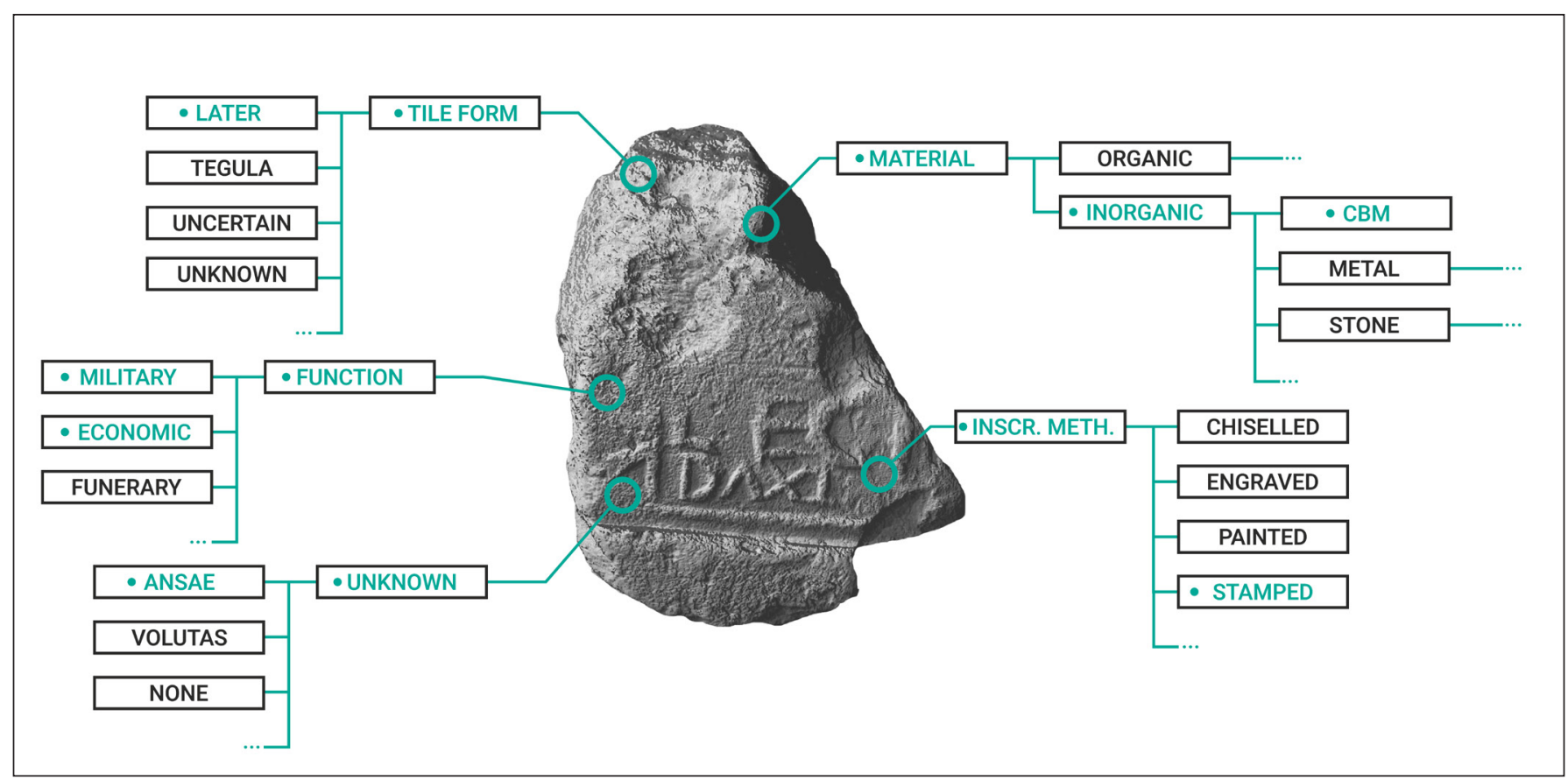

3. kép. Az adatbázis elemeinek tulajdonságait többlépcsős taxonómia rögzíti. Jelen ábra ezt a hierarchikus tulajdonság rendszert mutatja be grafikus úton, egy római tégla H-RTI felvételén keresztül (Készitette: Farkas István Gergö) 
Farkas István Gergö • A római bélyeges téglák és kerámia épitöanyagok (CBM) feldolgozására kialakitott CLIR adatbázis

Jelen tanulmány szempontjából az adatbázis legfontosabb elemeit a leletek jelentik. A Lelet (Finds) elemtípus a fent bemutatott három fó elemtípus bármelyikéhez hozzárendelhető, ezáltal az adatbázisban pontos, régészeti jelenség szintjén beazonosított leletek és ismeretlen, esetleg puszta lelőhelyhez köthető leletek egyaránt kezelhetők. A Személyek, Intézmények és Kutatási tevékenységek kiegészítő elemtípusai adminisztratív feladatot látnak el az adatbázisban, segítségükkel az adott leletanyag kezelői és szakértői könnyen beazonosíthatók.

Az adatbázis minden elemtípusához tartozik egy összetett adatlap, mezők és értékek sokaságával, amik elösegítik az egyes elemek azonosítását, lokalizációját, leírását stb. az elfogadott tudományos módszertannal összhangban. Az adatbázis hangsúlyos előnye, hogy minden elem tetszőleges számú attribútummal ruházható fel a hierarchikus rendben rögzített taxonómiákból (taxonomy term tree), ami összetett és sokrétü szürések és elemzések végzését teszi lehetővé (3. kép).

\section{JÖVŐBELI TERVEK}

A CLIR adatbázis CBM modul célja, hogy egy könnyen használható megoldást kínáljon nagy mennyiségü régészeti adat rögzítésére, elemzésére és kiértékelésére, együttmüködve más intézmények létező gyüjteményeivel, keretrendszereivel. A modul közzététele 2023 során várható, a fejlesztés és tesztelés időszaka jelen cikk írásakor (2021.11.12.) még nem zárult le. A modul keretében első ízben Baranya és Tolna megyék CBM anyaga kerül feltöltésre, mivel ezek minden jelentőségük ellenére e tekintetben egyelöre a kutatás szürke zónái.

\section{HIVATKOZÁSOK ÉS ONLINE TARTALMAK}

A CLIR adatbázis: https://clir.hu

A CLIR Kutatóközpont honlapja és blogja: https://www.clir-research.hu/

A CLIR program bemutatása: https://integralvision.hu/hu/munkak/clir

\section{FELHASZNÁLT IRODALOM}

Aubert, J.-J. (2005). L'estampillage des briques et des tuiles: une explication juridique sur une approche globale. In: C. Bruun (ed.), Interpretare i bolli laterizi di Roma e della Valle del Tevere: produzione, storia economica et topografia. Atti del convegno all'École française de Rome e all'Institutum Romanum Finlandiae, Rome, 31 mars-1er avril 2000, Institutum Romanum Finlandiae (pp. 53-59). Coll. Acta Instituti Romani Finlandiae 32. Róma: Institutum Romanum Finlandiae.

Betts, I. M. (1985). A Scientific Investigation of the Brick and Tile Industry of York to the Mid-Eightteenth Century. Unpublished PhD thesis. University of Bradford.

Borhy, L. \& Számadó, E. (2001). Beszámoló a Komárom/Szőny-Vásártér 2. számú háznál 1999-2001 folyamán végzett feltárásokról. Komárom Esztergom Megyei Önkormányzat Múzeumainak Közleménye 8 (2001), 143-162.

Borhy, L. (2014). Bibliography of the excavations in Brigetio (1992-2014). Dissertationes Archaeologicae ex Instituto Archaeologico Universitatis de Rolando Eötvös nominatae 3/2 (2014), 565-580. http://dx.doi. org/10.17204/dissarch.2014.565

Brodribb, G. (1989). Roman Brick and Tile. Gloucestershire: Alan Sutton Publishing. 
Farkas István Gergö • A római bélyeges téglák és kerámia épitöanyagok (CBM) feldolgozására kialakitott CLIR adatbázis

Clement, B. (2016). L'industrie de la brique crue dans la colonia Lugdunum (Lyon). In S. Camporeale, J. Delaine \& A. Pizzo (dir.), Arqueologia de la construccion V. Coll. Anejos de Archivo español de arqueología LXXVII (pp. 146-164). Oxford, 2016.

Czysz, W. (2001). Die spätrömische Töpferei und Ziegelei von Rohrbach im Landkreis Aichach-Friedberg - Ausgrabung des Brennofens 1 (1983). Berichte der Bayerischen Bodendenkmalpflege 41-42 (2000/2001), $129-159$.

Desbat, A. (1981). L'architecture de terre à Lyon à l'époque romain. In St. Walker (dir.), Récentes recherches en archéologie gallo-romaine et paléochrétienne sur Lyon et sa région (pp. 55-81). BAR International Series 108. Oxford: Archaeopress.

Farkas, I. G. (2019). (Notes from the trial of) the CLIR database. In I. G. Farkas, R. Neményi \& M. Szabó (eds), VISY75 Artificem commendat opus. Studia in honorem Zsolt Visy (pp. 159-165). Pécs: CLIR Research Center.

Farkas, I. G. (2020). New Roman Stamped Tiles from Altinum (Kölked). In I. G. Farkas, R. Neményi \& M. Szabó (eds), The Danube Limes in Hungary: Archaeological Research Conducted in 2015-2020 (pp. 255-271). Pécs: CLIR Research Center. https://doi.org/10.15170/CLIR.2020.11

Farkas, I. G. (2021). The CLIR database at https://clir.hu. In Zs. Visy (ed.), Proceedings of the Corpus Limitum Imperii Romani (CLIR) Online Conference Held on the 14 th of May, 2021 (pp. 23-34). Pécs: Hungarian Academy of Sciences, Pécs Regional Committee.

Ferdière, A. (2012). La production de terres cuites architecturales en Gaule et dans l'Occident romain, à la lumière de l'exemple de la Lyonnaise et des cités du nord-est de l'Aquitaine: un artisanat rural de caractère domanial? Revue archéeologique du Centre de la France 51 (2012), 17-187.

Grosschmied, G. (1836). Az ó-budai kis-sziget. Regélö 66 [1836. augusztus 18.], 521-523.

Havas, Z. (2005). Az óbudai hajógyári-szigeti helytartói palotakomplexum kerámia építészeti elemei. Szakdolgozat. Budapest: Eötvös Loránd Tudományegyetem, 2005.

Havas, Z. (2019). The Brick Architecture of the Governor 's Palace in Aquincum. PhD disszertáció. Budapest: Eötvös Loránd Tudományegyetem, 2019.

Janek, T. (2017). On the Production and Distribution of the Ceramic Building Material in Vindobona. Studia Hercynia 2, 1 (2017), 81-96.

Kovács, L. O. (2003). Égetett agyag tetőfedő elemek a táci római kori településröl. Szakdolgozat. Budapest, Eötvös Loránd Tudományegyetem, 2003.

Kovács, L. O. (2005). Égetett agyag tetőfedő elemek a táci római kori településről. Alba Regia. A Szent István Király Múzeum Évkönyve 35 (2005), 137-242.

Lőrincz, B. (1977). Pannonische Stempelziegel I: Limes-Strecke Annamatia-Ad Statuas. Dissertationes Archaeologicae ex Instituto Archaeologico Universitatis de Rolando Eötvös nominatae 2/5. Budapest: ELTE. 
Farkas István Gergö • A római bélyeges téglák és kerámia épitöanyagok (CBM) feldolgozására kialakitott CLIR adatbázis

Lőrincz, B. (1979). Pannonische Stempelziegel II: Limes-Strecke Vetus Salina-Intercisa. Dissertationes Archaeologicae ex Instituto Archaeologico Universitatis de Rolando Eötvös nominatae 2/7. Budapest: ELTE.

Lörincz, B. (1981). Pannonische Ziegelstempel III: Limes-Strecke Ad Felexum-Ad Mures. Dissertationes Archaeologicae ex Instituto Archaeologico Universitatis de Rolando Eötvös nominatae 2/9. Budapest: ELTE.

Malzbender, T., Gelb, D. \& Wolters, H. (2001) Polynomial texture map. Paper presented at the annual Special Interest Group on Graphics and Interactive Techniques (SIGGRAPH) conference, Los Angeles, USA, August 12-17, 2001.

McComish, J. M. (s. a.). An analysis of Roman Cerzmic Building Material from York and its Immediate Environs. Unpublished MA thesis. University of York.

McComish, J. M. (2015). A Guide to Ceramic Building Materials. York: York Archaeological Trust for Excavation and Research.

Mc Whirr, A. (1978). Roman Brick and Tile. Studies in Manufacture, Distribution, and Use in the Western Empire. British Archaeological Reports. International Series 68. Oxford: Archaeopress.

Pósta, B. (1897). Baranya vármegye története az őskortól a honfoglalásig. In Várady, F. (ed.), Baranya múltja és jelene, vol. II (pp. 5-208). Pécs, 1897.

Rómer, F. (1866). Magyar Régészeti Krónika. Archaeologiai Közlemények 6 (1866), 172, Nr. 882.

Szilágyi, J. (1933). Inscriptiones Tegularum Pannonicarum. Dissertationes Pannonicae ex Instituto Numismatico et Archaeologico Universitatis de Petro Pázmány nominatae Budapestiensis Provenientes 2/1. Budapest.

Torma, K. (1883). Római cserépedény bélyegek és karczolatok. Archaeologiai Értesítő 3 (1883), 1-72.

Visy, Zs. (2015). Corpus Limitis Imperii Romani (CLIR). In L. Vagalinski \& N. Sharankov (eds), Limes XXII: Roman Frontier Studies. Proceedings of the 22nd International Congress of Roman Frontier Studies. Ruse, Bulgaria, September 2012 (pp. 923-929). Bulletin of the National Institute of Archaeology 52. Sofia: Bulgarian Academy of Sciences, National Institute of Archaeology with Museum.

Warry, P. (2006). Tegulae: manufacture, typology and use in Roman Britain. British Archaeological Reports. British Series 417. Oxford: Archaeopress.

Wosinsky, M. (1896). Tolnavármegye története. Az öskortól a honfoglalásig vols. I-II, Budapest: Franklin. 